\title{
Editorial
}

\section{Value-based marketing strategies}

In business today marketing holds a paradoxical position. All companies now claim to understand the importance of brands and marketing and to be dedicated to developing strategies that create value for customers. At the same time, the marketing function appears to be diminishing in influence and to be disparaged as what the consultants $\mathrm{McK}$ insey called 'a millstone around an organisation's neck'. A recent survey by KPMG found finance directors rated marketing investment as the least important factor in contributing to a firm's long-term growth. They also said marketing and advertising are the first things they would cut if under pressure to reduce costs. Dominic Cadbury, Chairman of Cadbury Schweppes, summarised the situation, 'marketing has a struggle to be taken seriously in the boardroom and the notion of marketing as a source of competitive advantage is regarded with suspicion'. 1

The central problem is caused by marketing's failure to integrate itself with the firm's basic objective of maximising shareholder value. Marketing suffers both as a profession and an academic subject from having hazy objectives. Most marketing professionals believe that the objective of marketing is to increase sales or market share. But for an intelligent board of directors such an objective is patently absurd. Any first year economics student can demonstrate that maximising sales or share is an extremely unprofitable strategy. Another favoured goal of marketers is to develop strategies aimed at maximising customer satisfaction. But again this makes little sense. Lowering prices and increasing service can always increase customer satisfaction further, but the end result of such strategies will be very unhappy shareholders who find the company is making no profits.

An alternative tack pursued by some marketing managers intent on winning the confidence of the financial director is to develop strategies that maximise current profitability. Marketing expenditures are only proposed if they increase budgeted profits. But this is a hopeless trap for marketing. It means switching marketing spend from brand-building investments to short-term promotions. Because of the lagged effects of most brand investments, cutting rather than increasing these expenditures will always boost shortterm profitability. A focus on maximising profits is no help to anyone.

The starting point for increasing marketing's credibility in the boardroom is to properly define its objective. Today virtually all major companies accept that the primary task of management is to maximise returns to shareholders. The rationale for this goal lie in the property rights of shareholders and in capital market pressures to oust chief executives that do not deliver competitive returns. The objective of marketing needs to be redefined to align itself to this fundamental business goal. It can be restated as follows:

Marketing is the management process that seeks to maximise returns to shareholders by developing relationships with valued customers and creating a competitive advantage. Accepting this new concept of value-based marketing in no way weakens the traditional contribution of marketing; rather it enormously strengthens it. To understand this marketing managers need to appreciate how 
shareholder value is created. Shareholder value is the return investors obtain over a period in terms of dividends and share price appreciation. This return is based on the sum of all the firm's anticipated future economic profits, adjusted by an interest rate known as the cost of capital. If investors get more optimistic about the company's longterm prospects, the share price rises; if they become more pessimistic it falls. ${ }^{2}$

The key point is that investors look at long-term not short-run profits when valuing companies. In fact current profits typically explain less than 5 per cent of a company's value. Even profits over the next five years will usually account for less than 20 per cent of the share price. The evidence for this is all around today. It explains why Amazon.com, which has never made a profit, is valued at twice Cadbury Schweppes, which makes profits of nearly $£ 600$ million. It also explains why the share price usually drops when a company announces that it is cutting advertising or R\&D.

The shareholder value concept is an enormous potential asset for marketing professionals because marketing is the most important determinant of the firm's ability to achieve long-term profitable growth. It does this in three main ways. First, in-depth knowledge of customers enables marketing professionals to identify new growth opportunities. For example, Peter Davies and his marketing team transformed the stuffy Prudential to a dynamic financial services business by spotting the opportunities presented by the Internet. Second, marketing leads the development of strategies to identify highvalue customers and to build lasting relationships with them. Virgin is a classic example of such marketing leadership. Finally, marketing builds long-term earnings through developing strong brands that obtain enduring brand premiums. Brands like Coca-Cola, McDonalds, Disney and Kodak are powerful examples of how great brands create shareholder value.
Shareholder value analysis (SVA) - a relatively straightforward financial tool using a PC-based spreadsheet - enables marketing professionals to demonstrate how the strategies they are proposing enhance long-term earnings growth and produce specific, measurable increases in shareholder value. It enables marketing and brand building strategies to be rooted in the boardroom. The language of top management is finance. In the past marketing has been marginalised because it has not been able to communicate its contribution in financial terms. SVA could change all this for marketing managers making them key players in designing corporate strategies to enhance the firm's market value.

SVA encourages profitable marketing investments. Conventional accounting treats marketing expenditures as costs rather than investments in intangible assets such as brands and customer loyalty. Because the long-term profit streams generated by such investments are ignored, marketing in most businesses is underfunded. SVA, however, is future orientated: it encourages the longterm effects of marketing expenditures to be explicitly estimated. Many brand-building investments that would be quashed under traditional accounting procedures because they reduce current profits will be shown to be value creating under SVA. SVA also penalises arbitrary cuts in marketing budgets. It enables marketing managers to demonstrate that such cuts destroy value by eroding long term market share and brand premiums.

If marketing needs SVA to be credible, the shareholder value movement also needs marketing. SVA is a tool for evaluating strategies: it enables the board to choose between alternative policies. But what SVA cannot do is to create the strategies in the first place. All too often this role has been filled by financial management who have focussed on rationalisation as a way of increasing value. But what is clear today is that growth is the most effective way of cre- 
ating value for shareholders. All the companies that have created the greatest shareholder value in the last decade: Microsoft, Dell, Charles Schwab, Intel, the Gap have been high growth companies with strong brands. Only marketing focuses on the professional skills to create such strategies.

Peter Doyle Editorial Board

\section{ReferenCes}

(1) Butterfield, Leslie (ed.) (1999)

'Excellence in Advertising', Butterworth-Heinemann, Oxford.

(2) For a comprehensive account of shareholder value analysis see Copeland, Tom, Koller, Tim and Murrin, Jack (1996) 'Valuation:

Measuring and Managing the Value of Companies', Wiley, New York. 